\title{
Physiological potential of Stylosanthes spp. seeds cv. Campo Grande in response to coating with zinc and boron ${ }^{1}$
}

\author{
Priscilla Brites Xavier², Henrique Duarte Vieira², Mariá Moraes Amorim²
}

\begin{abstract}
The objective of this study was to evaluate the physiological potential of stylosanthes seeds cv. Campo Grande in response to coating with zinc and boron. The treatments were: T1 - uncoated seeds; T2 - seeds coated with calcium silicate; T3 - $80 \mathrm{~g}$ of B $+60 \mathrm{~g}$ of $\mathrm{Zn} \cdot \mathrm{kg}^{-1}$ seeds; T4 - $120 \mathrm{~g}$ of B $+90 \mathrm{~g}$ of $\mathrm{Zn} \cdot \mathrm{kg}^{-1}$ seeds; T5 - $160 \mathrm{~g}$ of B $+120 \mathrm{~g}$ of $\mathrm{Zn}^{\mathrm{kg}} \mathrm{kg}^{-1}$ of seed and; T6 $-200 \mathrm{~g}$ of $\mathrm{B}+150 \mathrm{~g}$ of $\mathrm{Zn}_{\mathrm{ng}} \mathrm{kg}^{-1}$ of seed. The seeds were evaluated by germination test, speed index and mean time of germination (GSI and MGT), seedlings emergence test, speed index and mean emergence time (ESI and MET), shoot and root length (SL and RL), leaf area (LA), number of nodes (NN) and shoot and root fresh (SFW and RFW) and dry weight (SDW and RDW). Coating reduced the germination and seed vigor. Micronutrients favored plants development, after its establishment. The coating with 120 $\mathrm{g}$ of $\mathrm{B}+90 \mathrm{~g}$ de $\mathrm{Zn} \cdot \mathrm{kg}^{-1}$ of seed favors the growth, development and nodulation of the plants.
\end{abstract}

Index terms: coating, seedlings emergence, micronutrients, vigor, Stylosanthes capitata/macrocephala.

\section{Potencial fisiológico de sementes de estilosantes cv. Campo Grande revestidas com zinco e boro}

\begin{abstract}
RESUMO - Avaliar o potencial fisiológico de sementes de estilosantes cv. Campo Grande em resposta ao recobrimento com zinco e boro foi o objetivo deste trabalho. Os tratamentos foram: T1 - sementes não recobertas; T2 - sementes recobertas com silicato de cálcio; T3 - $80 \mathrm{~g}$ de B + $60 \mathrm{~g}$ de Zn.kg-1 de sementes; T4 - $120 \mathrm{~g}$ de B + $90 \mathrm{~g}$ de Zn.kg-1 de sementes; T5 - $160 \mathrm{~g}$ de B + $120 \mathrm{~g}$ de Zn. $\mathrm{kg}^{-1}$ de sementes e; T6 - $200 \mathrm{~g}$ de B $+150 \mathrm{~g}$ de Zn. $\mathrm{kg}^{-1}$ de sementes. As sementes foram avaliadas pelos testes de germinação, índice de velocidade e tempo médio de germinação (IVG e TmG), emergência de plântulas, índice de velocidade e tempo médio de emergência (IVE e TmE), comprimento da parte aérea (CPA) e raiz (CR), área foliar (AF), número de nódulos (NN) e massa fresca e seca da parte aérea (MFPA e MSPA) e raiz (MFR e MSR). O recobrimento reduziu a germinação e o vigor das sementes. Os micronutrientes favoreceram o desenvolvimento das plantas, após seu estabelecimento. O recobrimento com $120 \mathrm{~g}$ de B + 90 $\mathrm{g}$ de $\mathrm{Zn} . \mathrm{kg}^{-1}$ de sementes favoreceu o crescimento, o desenvolvimento e a nodulação das plantas.
\end{abstract}

Termos para indexação: recobrimento, emergência de plântulas, micronutrientes, vigor, Stylosanthes capitata/macrocephala.

\section{Introduction}

In Brazil, the most practical and economical way of livestock support are the pastures. However, the results obtained with the production of dry mass are inferior to the genetic potential of the forage species, limiting the productive potential of the cattle industry (Victor et al., 2009), due to, in particular, the deficiency in fertilizer management. Therefore, the use of techniques aimed at improving this management emerges as viable alternatives to ensure the sustainability of the pastures cultivated by combining productivity, quality and persistence of forage production (Teles et al., 2011).

The brazilian cattle industry focuses, in large part, in the
Cerrado, which is characterized by the presence of micro aggregates that basically are mostly acidic soil with low capacity of cationic exchange (CTC) and high saturation by aluminum (Vendrame et al., 2010). Among the micronutrients, boron and zinc are worth highlighting, since they are the ones that most often cause disabilities in crops in soils of the Tropics (Faquin, 2005).

Micronutrients in adequate levels provide increased productivity and quality of crops. Appropriate levels of micronutrients can still encourage the efficient use of fertilizers containing nitrogen and phosphorus (Kirkby and Römheld, 2007). Boron and zinc are characterized by being absorbed in small quantities, due to the fact that they don't participate in plant

${ }^{1}$ Submitted on 05/19/2016. Accepted for publication on 09/01/2016.

${ }^{2}$ Universidade Estadual do Norte Fluminense, Laboratório de Fitotecnia, 28013-602 - Campos dos Goytacazes, RJ, Brasil.

*Corresponding author<pri_brites@yahoo.com.br> 
structures, but they are constituents of enzymes or act as its enablers (Dechen and Nachtigall, 2006).

Among the tasks assigned to boron, some can be highlighted, such as participation in the formation of the cell wall and plasma membrane (Malavolta, 2006), in the division and cell elongation in the transport of auxins and the nitrogenous base uracil synthesis, RNA component, affecting thus the synthesis of nucleic acid and protein (Faquin, 2005).

In addition, it has an important role in biological nitrogen fixation, because it protects the nitrogenase enzyme of damage caused by toxicity of reactive $\mathrm{O}_{2}$ species such as $\mathrm{O}_{2}$ and $\mathrm{H}_{2} \mathrm{O}_{2}$ (Malavolta, 2006).

The main function of zinc on the metabolism of plants is to work as an enzyme activator and component, being essential to the activity, regulation and stabilization of protein structure (Dechen and Nachtigall, 2006). $\mathrm{Zn}$ is also involved in the metabolism of auxins indole-3-acetic acid particularly (AIA) (Faquin, 2005; Kirkby and Römheld, 2007; Alloway, 2008).

Considering that the amount of micronutrients required by plants is small, the seed coating with micronutrients is an alternative supply, as it provides a better uniformity of distribution and utilization by plant, reduces losses, offers lower cost of implementation, in addition to improving the emergence and establishment of seedlings (Wazilewski and Gomes, 2009; Farooq et al., 2012). In addition, the technique of seed coating standardizes the size and the shape of the seed, providing greater precision in sowing and application of chemical products, especially with regard to small and irregularly-shaped seeds.

Although the coating technique promotes the application of micronutrients, the study of dose and ideal sources becomes important, since inadequate doses may cause toxicity affecting the physiological potential of seeds, as well as the development of plants in the field (Prado et al., 2007a). Therefore, it is important to assess that, while the addition of micronutrients to recoat can improve the physiological potential of seed, the same can also promote phytotoxicity problems, from inadequate doses.

The cv. estilosantes Campo Grande is a forage Fabaceae, launched by Embrapa in 2000, composed by physical mixture of improved seeds Stylosanthes capitata and Stylosanthes macrocephala, in proportion of $80 \%$ and $20 \%$, respectively (EMBRAPA Gado de Corte, 2007).

This Fabaceae is characterized by presenting several positive aspects to the use in pastures, such as: resistance to anthracnose; adaptation to sandy soils and low fertility; high productivity of seed (200 to $400 \mathrm{~kg} \cdot \mathrm{ha}^{-1}$ ); high capacity of natural re-sowing; good ability to persist in intercropping with Brachiaria decumbens; good digestibility and palatability; good getting nitrogen by biological fixation and; production of a good amount of dry matter ( 8 to $14 \mathrm{tha}^{-1}$ year-1) (EMBRAPA Gado de Corte, 2000; EMBRAPA Gado de Corte, 2007).

Therefore, the objective of this study was to evaluate the physiological potential of cv. estilosantes Campo Grande seeds in response to recoat with zinc and boron, from the hypothesis that the incorporation of micro-nutrients to the coating can improve germination and vigor of the seeds, as well as promote phytotoxicity problems.

\section{Material and Methods}

Commercial seed of stylosanthes cv. Campo Grande (Stylosanthes capitata/macrocephala), were used, which were previously subject to rip fence (Brasil, 2009) between two sheets of sandpaper number 100 , for overcoming dormancy. The information contained in the packaging of the seed lot were $98.5 \%$ purity and germination of $62 \%$. However, the tests were made of twinning and emergence of seedlings for characterization of the physiological quality of the lot, which provided the following values: $66 \%$ of germination; germination speed index of $16.77 ; 64 \%$ of emergence of seedlings and emergency speed index of 8.12.

As filling material for the coating process, calcium silicate and as cement material a solution of water and glue 'extra cascorez' based on polyvinyl acetate (PVA) were used, according to Xavier et al. (2015). The proportion of calcium silicate and seed was $3: 1(\mathrm{p} / \mathrm{p})$, respectively. The glue was diluted in water, previously heated to $70{ }^{\circ} \mathrm{C}$ (Mendonça et al., 2007), in a proportion of $1: 1(\mathrm{v} / \mathrm{v})$ for use as cement.

The sources of micronutrients were boric acid and zinc sulfate. The doses of micronutrients were based on recommendation of Malavolta (1980), for forage Fabaceae. From this recommendation the following treatments were established with the combinations of micronutrients: T1-seed not covered; T2-seeds covered only with calcium silicate; T3$80 \mathrm{~g}$ of boric acid and zinc sulfate $60 \mathrm{~g} \cdot \mathrm{kg}^{-1}$ of seeds; T4-120 $\mathrm{g}$ of boric acid and $90 \mathrm{~g}$ of zinc sulphate $\mathrm{kg}^{-1}$. of seeds; T5-160 $\mathrm{g}$ of boric acid and zinc sulfate $120 \mathrm{~g}$. $\mathrm{kg}^{-1}$ and seeds; T6-200 g of boric acid and zinc sulfate $150 \mathrm{~g} . \mathrm{kg}^{-1}$ of seeds.

In the coating process, a bench model drageadora N10 Newpack was used, adjusted to work with rotation speed $90 \mathrm{rpm}$ tub, time of application of cement solution spray of 1 second, air blower temperature of $40^{\circ} \mathrm{C}$ and duration time of the blower attached to 1 minute. A methodology for materials deposition in layers was performed according to Xavier et al. (2015), however, the amounts of micronutrients have been added, all at once, on the sixth covering layer, starting with the boric acid followed by zinc sulphate. 
After recovering, the seeds were evaluated as physiological characteristics in laboratory and vegetation, as follows:

Germination test-carried out according to the modification of the Rules for Seed Testing (Brasil, 2009), for the number of seeds by replication, with four replications of 50 seeds each, for each treatment. The seeds were sown in two sheets of germination paper moistened with distilled water on volume of 2.5 times the mass of the substrate and kept for 10 days, in the germination Chamber type BOD with alternating temperature of $20 / 35{ }^{\circ} \mathrm{C}$. The evaluations were carried out according to Brasil (2009). Daily counts were performed for determining the germination speed index (GSI) by the formula proposed by Maguire (1962), and the mean germination time (MGT), according to Edmond and Drapala (1958).

Seedling emergence test - was performed in a greenhouse, with four replications of 50 seeds for each treatment, where the seeds were sown in plastic trays, with a capacity of 2.2 liters of substrate containing a mixture of sand and soil $(2: 1)$ $(\mathrm{v} / \mathrm{v})$. Daily counts were made of the number of emerged seedlings for a period of 30 days. In the end, the percentage of seedling emergence (E) was determined, these being considered from its emergence in the substrate, the speed index (ESI), second formula adapted from Maguire (1962), and the mean emergence time (MET), (Edmond and Drapala, 1958). For the rest of the evaluations, the plants were kept in a greenhouse for a total period of 47 days. In the end, the plants were carefully removed from the trays and had their roots properly washed and then analyze the equipment ground eye $\mathrm{S} 120^{\circledR}$ which supplied the data related to the length of the shoot (SL) and root (RL) in centimeters and nodule/plant number $(\mathrm{NN})$. For leaf area in $\mathrm{cm}^{2}$ (LA), the fully expanded leaves were highlighted and analyzed by ground eye $\mathrm{S} 120^{\circledR}$ equipment. Subsequently, the aerial part was separated from the root and both were placed in paper bags and heavy in balance of precision for determination of fresh weight of the shoot (SFW) and root (RFW) in mg per plant. Then the bags were kept in forced air circulation oven at $65^{\circ} \mathrm{C}$ for 72 hours to determine the dry weight of the shoot (SDW) and root (RDW) in mg per plant.

For statistical analysis we used the model of completely randomized design, with four replications of 50 seeds, for the variables: FGC, G, AS, SD, DS, GSI, and MGT for the experiment in vegetation was used a model of random blocks design with four replications of 50 seeds each. For the statistical analysis of the variables, SL, RL, SFW, SDW, RFW, RDW, LA and NN 20 plants were used, with five plants of each block, taken at random. G data, AP and DS were transformed to arcoseno (x/100).5, to follow normal distribution. Subsequently, data were subjected to analysis of variance and averages compared by Duncan test at $5 \%$ probability.

\section{Results and Discussion}

The treatments influenced the physiological quality of seeds of cv. estilosantes Campo Grande (Table 1). The treatments involving the covering of seeds, regardless of the addition of $\mathrm{Zn}$ and B, exerted negative impact on the first count of germination (FGC). None of the treatments proved superior to the seed not covered, especially on treatment 6 (addition of $200 \mathrm{~g}$ of boric acid and zinc sulfate $150 \mathrm{~g} . \mathrm{kg}^{-1}$ of seeds) in which the scored percentage of germination in the first test was equal to zero.

Table 1. First Germination Count (FGC) (\%), Germination Speed Index (GSI), Mean Germination Time (MGT) (days), Germination (\%), Abnormal Seedlings (AS) (\%) and Dead Seeds (DS) (\%) of estilosantes cv. Campo Grande recoated.

\begin{tabular}{|c|c|c|c|c|c|c|}
\hline Treatment* & FGC & GSI & MGT & G & AS & DS \\
\hline 1 & $51 \mathrm{a}$ & $16.88 \mathrm{a}$ & $2.51 \mathrm{a}$ & $75 \mathrm{a}$ & $3 a$ & $19 \mathrm{a}$ \\
\hline 2 & $28 \mathrm{~b}$ & $15.55 \mathrm{a}$ & $2.54 \mathrm{a}$ & $66 \mathrm{~b}$ & $7 \mathrm{ab}$ & $13 \mathrm{bc}$ \\
\hline 3 & $33 \mathrm{~b}$ & $14.86 \mathrm{ab}$ & $2.77 \mathrm{a}$ & $63 \mathrm{~b}$ & $10 \mathrm{~b}$ & $13 \mathrm{bc}$ \\
\hline 4 & $29 \mathrm{~b}$ & $13.12 \mathrm{~b}$ & $2.81 \mathrm{a}$ & $59 \mathrm{~b}$ & $7 \mathrm{ab}$ & $16 \mathrm{ab}$ \\
\hline 5 & $9 \mathrm{c}$ & $12.55 \mathrm{~b}$ & $3.20 \mathrm{a}$ & $44 \mathrm{c}$ & $25 \mathrm{c}$ & $11 \mathrm{c}$ \\
\hline 6 & $0 \mathrm{c}$ & $6.45 \mathrm{c}$ & $3.67 \mathrm{a}$ & $23 \mathrm{~d}$ & $24 \mathrm{c}$ & $13 \mathrm{bc}$ \\
\hline Mean & 24.8 & 13.23 & 2.91 & 55 & 12.7 & 14 \\
\hline CV (\%) & 30.58 & 11.19 & 32.74 & 7.72 & 29.90 & 19.61 \\
\hline
\end{tabular}

Mean followed by the same letter did not differ statistically between each other by Duncan test $(\mathrm{p}<0.05)$.

*T1 - uncoated seeds; T2 - seeds coated with calcium silicate; T3 - $80 \mathrm{~g}$ of B $+60 \mathrm{~g}$ of Zn.kg-1 seeds; T4 - $120 \mathrm{~g}$ of B $+90 \mathrm{~g}$ of Zn.kg $\mathrm{kg}^{-1}$ seeds; T5 - $160 \mathrm{~g}$ of B + $120 \mathrm{~g}$ of $\mathrm{Zn} \cdot \mathrm{kg}^{-1}$ of seed and; T6 - $200 \mathrm{~g}$ of B $+150 \mathrm{~g}$ of $\mathrm{Zn} \cdot \mathrm{kg}^{-1}$ of seed.

Some authors, in contrast, didn't check effect of zinc and boron coating on FGC of rice and wheat seeds (Tavares et al., 2013a; Tavares et al., 2013b). However, it is noteworthy that the largest doses $\left(0.25\right.$ and 8.4 g. $\mathrm{kg}^{-1}$ of $\mathrm{Zn}$ and $\mathrm{B}$ for rice and 
0.73 and 0.03 g.kg-1 of $\mathrm{Zn}$ and B for wheat, respectively) used in rice and wheat seeds were much smaller when compared to those employed in this work. Probably the reduction observed in the FGC is associated with osmotic effect provided by micronutrients.

The seeds yield or absorb water of the substrate, with greater or lesser speed, according to water gradient between the seed and the external environment (Lopes and Macedo, 2008). A high concentration of salts is characterized as a stress factor for plants, since this salinity entails reducing the osmotic potential which therefore favours the retention of water in order to make it less available for plants (Ribeiro et al., 2001). Thus, with increasing salinity occurs a decrease in osmotic potential, making water absorption by the roots more difficult (Amorim et al., 2002).

Fertilizers used as source of micronutrients are characterized by being salts and the presence of these interfering with the covering the surrounding water potential of the seed by reducing the potential gradient between the seed surface and coating, which ends up restricting the water absorption and, therefore, reducing seed germination. Even the pure silicate coating without the addition of micronutrients has caused negative impact on the FGC.

The effect of coating with zinc and boron was also noticed in the germination speed index (GSI). However, the same did not affect the mean germination time (MGT) (Table 1). Similarly, all treatments interfered negatively in the germination percentage at the end of the test, where he observed the worst results for treatments 5 and 6 (44 and 23\%, respectively) (Table 1 ).

Similar results were observed by Ribeiro et al. (1994) on germination of maize seeds coated with $\mathrm{Zn}$ and B and for sorghum seeds (Yagi et al., 2006) and rice (Funguetto, 2007) covered with Zn. However, several authors report that the seed coating with these micronutrients either applied alone or in combination, does not affect the germination (Ohse et al., 2000; Masuthi et al., 2009; Tavares et al., 2013a; Tavares et al., 2013b; Tavares et al., 2013c; Arjmand et al., 2014; Oliveira et al., 2014). However, it is noteworthy that the species used in this study differs from the species evaluated by the authors mentioned and the doses of micronutrients were employed higher than those used for the same. In addition, the reduction in the final germination percentage observed reinforces the hypothesis of the influence exercised by these micronutrients in the water potential of the coating reducing water uptake by seeds.

From the data relating to abnormal seedlings (AS) was unable to verify the negative effect of the treatments (Table 1). The smallest percentages of AS were observed in treatments 5 and 6 , comprise the combinations of the largest doses of micronutrients, which may be related, in addition to the osmotic effect of flooring, a larger doses from these toxicity, since these micronutrients are required in small amounts and the range between the ideal and the toxic quantity is small. According to Prado et al. (2007a) inadequate doses of micronutrients can cause toxicity, affecting plant growth and, consequently, reducing the rate of germination and emergence, reducing the range of plants and the production of culture.

On the other hand, the largest percentages of dead seeds (DS) were observed for treatment 1 (seeds not covered), which differed from treatment 4 (Table 1). In this way, one can infer that the covering of seeds of cv. stylosanthes Campo Grande, adding micronutrients or not, does not result in death of seeds, and even the combinations with the highest doses do not cause this effect, although it can cause a phytotoxic effect, as mentioned for AS.

All treatments in which there was addition of micronutrients in smaller percentages were provided covering of emergence of seedlings, however, for the emergency speed index (ESI) the same did not differ from the control (Table 2). Treatment 2, constituted only of coating with calcium silicate, showed the best results for the ESI and the addition of micronutrients to recoat it hasn't hurt the mean emergence time (MET), where all treatments with micronutrients were equal to or better than the control.

Table 2. Emergence (E), Emergence Speed Index (ESI), Mean Emergence Time (MET), of estilosantes cv. Campo Grande seedlings from coated seeds.

\begin{tabular}{cccc}
\hline Treatment* $^{*}$ & E (\%) & ESI & MET (days) \\
\hline 1 & $76 \mathrm{a}$ & $7.03 \mathrm{~b}$ & $6.24 \mathrm{~b}$ \\
2 & $72 \mathrm{a}$ & $8.95 \mathrm{a}$ & $4.71 \mathrm{a}$ \\
3 & $55 \mathrm{~b}$ & $5.99 \mathrm{~b}$ & $5.41 \mathrm{ab}$ \\
4 & $60 \mathrm{~b}$ & $7.00 \mathrm{~b}$ & $4.79 \mathrm{a}$ \\
5 & $57 \mathrm{~b}$ & $6.81 \mathrm{~b}$ & $5.00 \mathrm{a}$ \\
6 & $50 \mathrm{~b}$ & $5.72 \mathrm{~b}$ & $4.98 \mathrm{a}$ \\
\hline Mean & 61.5 & 6.92 & 5.19 \\
CV $(\%)$ & 11.56 & 16.03 & 11.88
\end{tabular}

Mean followed by the same letter did not differ statisticaly between each other by Duncan test $(\mathrm{p}<0.05)$.

*T1 - uncoated seeds; T2 - seeds coated with calcium silicate; T3 - $80 \mathrm{~g}$ of B $+60 \mathrm{~g}$ of Zn.kg-1 seeds; T4 - $120 \mathrm{~g}$ of B $+90 \mathrm{~g}$ of Zn.kg-1 seeds; T5 - $160 \mathrm{~g}$ of $\mathrm{B}+120 \mathrm{~g}$ of Zn. $\mathrm{kg}^{-1}$ of seed and; T6 - $200 \mathrm{~g}$ of B $+150 \mathrm{~g}$ of Zn. $\mathrm{kg}^{-1}$ of seed.

Tavares et al. (2013c), evaluating the effect of different

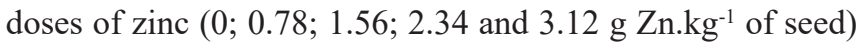
of seed coating of oatmeal, did not verify any differences between the doses employed, in the same way as for the control, when compared by average test. However, it is important to note that the doses used by authors were much smaller when compared to the ones employed in this work. Therefore, one can infer that, again, the osmotic effect of 
micronutrients may have interfered in the water potential of the coating, leading to decreases in speed of water absorption, which consequently reduced the emergence of plants.

The addition of micronutrients to recoat did not affect the speed of emergence of plants when compared to seed not covered (treatment 1). Similarly, Arjmand et al. (2014) also observed no difference in speed of emergence of barley plants, relative to the control, depending on the use of different doses

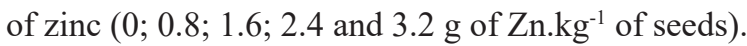

For the variable length of the shoot (SL) there was a positive effect of the addition of micronutrients coating (Table 3). The lowest values were obtained in plants from seed not covered and covered only with calcium silicate, which did not differ among themselves. Among the treatments with addition of micronutrients, treatment 4 ( $120 \mathrm{~g}$ of boric acid and $90 \mathrm{~g}$ of zinc sulphate $\mathrm{kg}^{-1}$ of seeds) presented the highest values for this variable, however, not statistically different from treatments 3 and 5. On the other hand, treatment 6 (T6-200 g of boric acid and zinc sulfate 150 g. $\mathrm{kg}^{-1}$ of seeds), one of the compounds by micronutrients, provided the lowest SL.

Treatment 4 provided the best values of root length (RL), as opposed to treatment 6 , which resulted in the lower RL, not differing from the seeds not covered (Table 3).

Table 3. Shoot Lenght (SL) (cm), Root Lenght (RL) (cm), Leaf Area (LA) $\left(\mathrm{cm}^{2}\right)$, Number of Nodules per plant (NN), Fresh Weight of the Shoot (SFW) (mg.plant ${ }^{-1}$ ), Dry Weight of the shoot (SDW) (mg.plant ${ }^{-1}$ ), Fresh Weight of the Root (RFW) (mg.plant $\left.{ }^{-1}\right)$ and Dry Weight of the Root (RDW) (mg.plant ${ }^{-1}$ ) of estilosantes cv. Campo Grande plants from coated seeds.

\begin{tabular}{cllllllll}
\hline Treatment* & SL & RL & LA & NN & SFW & SDW & RFW & RDW \\
\hline 1 & $2.74 \mathrm{~d}$ & $14.50 \mathrm{~cd}$ & $0.41 \mathrm{c}$ & $6 \mathrm{bc}$ & $134.55 \mathrm{~b}$ & $71.25 \mathrm{a}$ & $98.30 \mathrm{c}$ & $84.95 \mathrm{~b}$ \\
2 & $2.95 \mathrm{~cd}$ & $17.42 \mathrm{~b}$ & $0.49 \mathrm{ab}$ & $6 \mathrm{bc}$ & $159.40 \mathrm{a}$ & $77.89 \mathrm{a}$ & $116.30 \mathrm{a}$ & $96.75 \mathrm{a}$ \\
3 & $3.13 \mathrm{ab}$ & $17.05 \mathrm{bc}$ & $0.51 \mathrm{ab}$ & $7 \mathrm{ab}$ & $156.15 \mathrm{a}$ & $77.90 \mathrm{a}$ & $111.40 \mathrm{ab}$ & $87.25 \mathrm{ab}$ \\
4 & $3.41 \mathrm{a}$ & $22.56 \mathrm{a}$ & $0.53 \mathrm{a}$ & $8 \mathrm{a}$ & $137.45 \mathrm{~b}$ & $58.00 \mathrm{~b}$ & $112.35 \mathrm{ab}$ & $76.25 \mathrm{~b}$ \\
5 & $3.36 \mathrm{ab}$ & $18.74 \mathrm{~b}$ & $0.43 \mathrm{bc}$ & $3 \mathrm{~d}$ & $131.80 \mathrm{~b}$ & $71.35 \mathrm{a}$ & $99.90 \mathrm{c}$ & $78.40 \mathrm{~b}$ \\
6 & $3.04 \mathrm{bc}$ & $13.90 \mathrm{~d}$ & $0.50 \mathrm{ab}$ & $4 \mathrm{~d}$ & $143.45 \mathrm{ab}$ & $71.40 \mathrm{a}$ & $104.35 \mathrm{bc}$ & $83.55 \mathrm{~b}$ \\
\hline Mean & 3.11 & 17.36 & 0.48 & 5.66 & 143.80 & 71.28 & 107.10 & 84.53 \\
CV (\%) & 15.71 & 24.48 & 27.52 & 41.80 & 17.37 & 26.07 & 13.84 & 20.38 \\
\hline
\end{tabular}

Mean followed by the same letter did not differ statistically between each other by Duncan test $(\mathrm{p}<0.05)$.

*T1 - uncoated seeds; T2 - seeds coated with calcium silicate; T3 - $80 \mathrm{~g}$ of B $+60 \mathrm{~g}$ of Zn.kg-1 seeds; T4 - $120 \mathrm{~g}$ of B + $90 \mathrm{~g}$ of Zn.kg-1 seeds; T5 - $160 \mathrm{~g}$ of B + $120 \mathrm{~g}$ of Zn.kg-1 of seed and; T6 - $200 \mathrm{~g}$ of B + $150 \mathrm{~g}$ of Zn. $\mathrm{kg}^{-1}$ of seed.

The positive effects observed for SL and RL, can be related to participation of $\mathrm{Zn}$ in the synthesis of tryptophan, which seems to be the precursor of the biosynthesis of indole-3-acetic acid (IAA), which is the main promoter of growth hormone in plants (Faquin, 2005; Kirkby and Römheld, 2007; Alloway, 2008). Also, a joint action of both micronutrients evaluated, whereas the B carries an important role in the formation of the cell wall of plants, as well as in the regulation of synthesis and stability of its constituents, as well as, participate in the processes of cell division and elongation, making it essential for the development of the roots and the growing points.

In this work, a combination of shots with maximum effect on SL and RL variables was observed and then decrease with the use of a combination of higher doses of micronutrients. Results that corroborate the observed in this work were found by several authors for the SL and RL, but with other species, is seed coating with $\mathrm{Zn}$ and $\mathrm{B}$ combined or in the use of these isolated way (Ohse et al., 2000; Funguetto, 2007; Masuthi et al., 2009; Tavares et al., 2013a; Tavares et al., 2013). However,
Ohse et al. (2000) achieved better results for zinc applied separately and negative for the shoot, root and whole plant length of rice when the seeds were given in $\mathrm{B}+\mathrm{Zn}$ coating together. According to the authors, these results are probably the antagonistic effect of these micronutrients. In the present work the negative effect in treatment 6 (T6-200 g of boric acid and zinc sulfate $150 \mathrm{~g} \cdot \mathrm{kg}^{-1}$ of seeds), possibly the beginning of phytotoxic effect of doses of these micronutrients.

In relation to leaf area (LA), again the treatment 4 (T4-120 $\mathrm{g}$ of boric acid and $90 \mathrm{~g}$ of zinc sulphate $\mathrm{kg}^{-1}$ of seed) is shown higher than the control (treatment 1), however treatments 2, 3 and 6 did not differ from the T4 (Table 3). Tavares et al. (2013a) also observed increments in LA of rice plants obtained from seeds coated with $\mathrm{Zn}$ and $\mathrm{B}$ as the doses tested increased (maximum

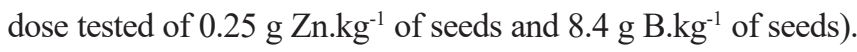
The authors evaluated two products, one of which was composed only for $\mathrm{Zn}$ and the other by mixing this with $\mathrm{B}$ and Mo, and there have been no difference between the same. Similarly, the use of these same products also provided in increments of LA values 
of wheat plants on the grounds of increased doses (maximum dose tested of $3.12 \mathrm{~g} \mathrm{Zn} . \mathrm{kg}^{-1}$ of seeds and $0.03 \mathrm{~g} \mathrm{~B} \cdot \mathrm{kg}^{-1}$ of seeds) (Tavares et al., 2013b). These results corroborate with those found for plants of oats covered with $\mathrm{Zn}$ (at a dose of $3.12 \mathrm{~g}$ Zn.kg-1 of seeds) (Oliveira et al., 2014).

It is important to highlight that the doses evaluated in the works mentioned are tiny compared to those used in this study. This is due to the use of commercial formulations, for these authors, which have a recommended dosage for the main crops, different from this work that followed a specific recommendation to forage Fabaceae (Malavolta, 1980).

To the variable number of nodes (NN), treatment 4 also provided the best results, and treatments 5 and 6 provided in the lowest values, demonstrating inhibitory effect of doses used in these treatments (Table 3).

The Fabaceae, like stylosanthes, are characterized by their ability to bind to bacteria capable of fixing atmospheric nitrogen and convert it into ammonia, which will be embedded into forms of possible nitrogen for use by these plants (Araújo and Carvalho, 2006). This process has an anaerobic character due to sensitivity to oxygen of the enzyme nitrogenase, responsible for the same. Therefore, the amount of oxygen required to cellular respiration, must be controlled without the impairment of enzyme activity (Faquin, 2005). It is believed that the oxygen control mechanism is related to the performance of boron in the cell wall, seen that there is a relationship between the Fabaceae and the Rhizobium membranes (Bolaños et al., 1996). As boron regulates the synthesis and stability of cell wall constituents, if there is a deficiency of this micronutrient, the barrier that manages the diffusion of oxygen from outside the infected area by the lump can be broken, undermining the activity of the enzyme and, consequently, efficiency biological nitrogen fixation (Yamagishi and Yamamoto, 1994).

For the fresh weight from the shoot (SFW) and dry weight from the shoot (SDW), treatment 4 did not stand out of control as it was checked for SL, RL, LA and NN (Table 3). For treatments 2 and 3 SFW provided the best results, and treatment 6 did not differ from these. On the other hand, treatment 4 presented the smallest observed values for SDW. These results may be related to a better photosynthetic efficiency of plants from treatments with lower leaf area (treatments 2, 3 and 6), which may have been able to intercept the light energy and $\mathrm{CO}_{2}$, to dry weight production, better than plants with greater FA (4) (Tavares et al., 2013).

The best results for root fresh weight (RFW) and root dry weight (RDW) were observed for plants from the treatment 2 , however, the treatments 3 and 4 (with different combinations of $\mathrm{Zn}$ and $\mathrm{B}$ ) did not differ to RFW and treatment 3 did not differ from the 2 as the RDW (Table 3). It is important to emphasize the improvement of the development of plants from seeds coated in relation to the control.

Ohse et al. (2000) did not notice significant difference in dry weight of aerial and total irrigated rice plants from seeds coated with $\mathrm{Zn}$ and $\mathrm{B}$, and the same was observed for plant dry weight of bean pods (Masuthi et al., 2009) and wheat from seeds coated with different doses of zinc (Tavares et al., 2013b). In addition, some authors have reported a negative effect of $\mathrm{Zn}$ on RDW and total dry weight of sorghum and maize plants when used zinc sulphate as a source of micronutrient in the light of increasing doses (Yagi et al., 2006; Prado et al., 2007a, Prado and Mouro, 2007b). This effect may be the result of excess $\mathrm{Zn}$ added to the concentration already present on the seeds of this micronutrient, causing inhibition of root elongation (Yagi et al., 2006).

Positive results of the seed coating for SDW and RDW with $\mathrm{Zn}$ and $\mathrm{B}$ were described in rice plants irrigated and dry mass of wheat plants from seeds coated with $\mathrm{Zn}$, SDW of rice plants from seeds coated with $\mathrm{Zn}, \mathrm{B}$ and Mo and plant dry weight of oats from the covering with Zn (Funguetto, 2007; Tavares et al., 2013b; Tavares et al., 2013a; Oliveira et al., 2014).

From the foregoing it was possible to observe that the covering of seeds of cv. stylosanthes Campo Grande, regardless of the addition or not of micronutrients, impaired germination and the combination of higher doses of $\mathrm{Zn}$ and $\mathrm{B}$ the impact of covering the worst germination speed index, despite that the covering did not interfere in the time of germination. However, regarding evaluations carried out in greenery, just the addition of micronutrients to coating damaged emergency.

As for the biometric characteristics, some treatments with addition of micronutrients proved superior to the control, in cases such as for SL, RL, LA and NN. Despite not having differed from other treatments added micronutrients, treatment 4 (120 g of boric acid and $90 \mathrm{~g}$ of zinc sulphate. $\mathrm{kg}^{-1}$ of seeds) led to increments in the length of the shoot, root, leaf area and number of nodules of the orders of $25 \%, 55 \%, 29 \%$ and $33 \%$, respectively, relative to the control, in addition to having to promoted the best value for root length $(22.56 \mathrm{~cm})$. However, these results have not been verified for the fresh and dry weight of shoots and root.

Thus, one can infer that it compromises the potential physiological coating of the seeds of stylosanthes, which would affect the establishment of the stand of plants in the field. However, after the establishment of seedlings, the micronutrients promote their development. Therefore, once the micronutrients are required in small quantities by plants, and from the results, it is necessary to carry out new tests 
to assess smaller doses, in order that we can recommend an appropriate dose for veneering of stylosanthes seeds cv. Campo Grande with the micronutrients zinc and boron.

\section{Conclusions}

The covering of seeds of stylosanthes cv. Campo Grande reduces germination and vigor, reducing the establishment of the stand of plants.

Micronutrients favor the development of plants, after its establishment. Treatment with $120 \mathrm{~g}$ of boric acid and $90 \mathrm{~g}$ of zinc sulphate. $\mathrm{kg}^{-1}$ of seeds promotes the growth, development and nodulation of stylosanthes plants cv. Campo Grande.

\section{References}

AMORIM, J. R. A.; FERNANDES, P. D.; GHEYI, H. R.; AZEVEDO, N. C. Efeito da salinidade e modo de aplicação de água de irrigação no crescimento e produção de alho. Pesquisa Agropecuária Brasileira, v.37, p.167-176, 2002. http://www.scielo.br/pdf/pab/v37n2/9051.pdf

ALLOWAY, B. J. Zinc in soils and crop nutrition. 2ed. Bruxelas: International Zinc, 2008. 135p.

ARAÚJO, A. S. F.; CARVALHO, E. M. S. Fixação biológica de nitrogênio em fabáceas. Universidade Federal do Piauí. Comunicado Técnico, v.11, p.1-4, 2006.

ARJMAND, H. S.; ABARGHOOEI, G. H. B.; GHORBANPOUR, M.; SHARAFI, S. Effect of zinc coated during storage in the seed quality of barley. International Journal of Farming and Allied Science, v.3, p.845-850, 2014. http://ijfas.com/wp-content/uploads/2014/08/845-850.pdf

BOLAÑOS, L.; BREWIN, N. J.; BONILLA, I. Effects of boron on Rhizobium-legume cell-surface interactions and nodule development. Plant Physiology, v.110, p.1249-1256, 1996. http://www.ncbi.nlm.nih.gov/pmc/ articles/PMC160918/pdf/1101249.pdf

BRASIL. Ministério da Agricultura, Pecuária e Abastecimento. Regras para análise de sementes. Ministério da Agricultura, Pecuária e Abastecimento. Secretaria de Defesa Agropecuária. Brasília: MAPA/ACS, 2009. 395p. http:// www.agricultura.gov.br/arq_editor/file/2946_regras_analise_sementes.pdf

DECHEN, A. R.; NACHTIGALL, G. R. Micronutrientes. In: FERNANDES, M. S. Nutrição mineral de plantas. Viçosa: Sociedade Brasileira de Ciência do Solo, 2006. p. 327-354.

EDMOND, J.B.; DRAPALA, W.J. The effects of temperature, sand and soil, and acetone on germination of okra seed. Proceedings of the American Society for Horticultural Science, v.71, p.428-434, 1958.

EMBRAPA GADO DE CORTE. Estilosantes Campo Grande. Embrapa Gado de Corte - Campo Grande - MS. Gado de Corte Divulga, v.38, 2p. 2000.

EMBRAPA GADO DE CORTE. Cultivo e uso do estilosantes-campo-grande. Embrapa Gado de Corte-Campo Grande-MS. Comunicado Técnico, v.105, $11 \mathrm{p}, 2007$.

FAQUIN, V. Nutrição mineral de plantas. Lavras: UFLA/FAEPE, 2005. 179p.

FAROOQ, M.; WAHID, A.; SIDDIQUE, K. H. M. Micronutrient application through seed treatments - a review. Journal of Soil Science and Plant Nutrition, v.12, p.125-142, 2012. http://www.scielo.cl/pdf/jsspn/v12n1/art11.pdf
FUNGUETTO, C. I. Recobrimento de sementes de arroz irrigado com zinco e polímero. Norte Cientifico, v.2, p.80-92, 2007. http://wilikit.ifrr.edu.br/SISTEMAS/revista/index.php/revista/article/ view/54/53

KIRKBY, E. A.; RÖMHELD, V. Micronutrientes na fisiologia de plantas: funções, absorção e mobilidade. Encarte Técnico, Informações Agronômicas, v.118, 2007. 24p.

LOPES, J. C.; MACEDO, C. M. P. Germinação de sementes de couve chinesa sob influência do teor de água, substrato e estresse salino. Revista Brasileira de Sementes, v.30, p.79-85, 2008. http://www.scielo.br/pdf/rbs/v30n3/11.pdf

MAGUIRE, J. D. Speeds of germination-aid selection and evaluation for seedling emergence and vigor. Crop Science, v.2, p.176-177, 1962.

MALAVOLTA, E. Elementos de nutrição mineral de plantas. São Paulo: Ceres, 1980.251p

MALAVOLTA, E. Manual de nutrição mineral de plantas. São Paulo: Ceres, 2006. 631p

MASUTHI，D. A.;VYAKARANAHAL，B. S.; DESHPANDE，V. K Influence of pelleting with micronutrients and botanical on growth, seed yield and quality of vegetable cowpea. Karnataka Journal of Agricultural Sciences, v.22, p.898-900, 2009. http://14.139.155.167/test5/index.php/kjas/ article/viewFile/1575/1566

MENDONCA, E.A F.; CARVALHO, N.M.; RAMOS, N.P. Revestimento de sementes de milho superdoce $\left(\mathrm{Sh}_{2}\right)$. Revista Brasileira de Sementes, v.29, p.68-79, 2007. http://www.scielo.br/pdf/rbs/v29n2/v29n2a10.pdf

OHSE, S.; MARODIM, V.; SANTOS, O. S.; LOPES, S. J.; MANFRON, P. A. Germinação e vigor de sementes de arroz irrigado tratadas com zinco, boro e cobre. Uruguaiana, v.7, p. 41-50, 2000. http://revistaseletronicas. pucrs.br/ojs/index.php/fzva/article/view/2055/1549

OLIVEIRA, S.; TAVARES, L. C.; LEMES, E. S.; BRUNES, A. P.; DIAS, I. L.; MENEGHELLO, G. E. Tratamento de sementes de Avena sativa 1. com zinco: qualidade fisiológica e desempenho inicial de plantas. Semina: Ciências Agrárias, v.35, p.1131-1142, 2014. http://www.uel.br/revistas/uel/ index.php/semagrarias/article/view/13599/14517

PRADO, R. M.; NATALE, W.; MOURO, M. C. Fontes de zinco aplicado via semente na nutrição e crescimento inicial do milho cv. Fort. Bioscience Journal, v.23, p.16-24, 2007a. http://www.seer.ufu.br/index.php/ biosciencejournal/article/viewFile/6375/4117

PRADO, R. M.; MOURO, M. C. Fontes de zinco aplicado em sementes de sorgo cv. BRS 310 e o crescimento inicial. Semina: Ciências Agrárias, v.28, p.355-364, 2007b. http://www.uel.br/revistas/uel/index.php/semagrarias/ article/view/2958/2505

RIBEIRO, M. C. C.; MARQUES, B. M.; AMARO FILHO, J. Efeito da salinidade na germinação de sementes de quatro cultivares de girassol (Helianthus annuus L.). Revista Brasileira de Sementes, v.23, n.1, p.281-284, 2001. http://www.abrates.org.br/revista/artigos/2001/v23n1/artigo39.pdf

RIBEIRO, N. D.; SANTOS, O. S.; MENEZES, N. L. Tratamento de sementes de milho com fontes de zinco e boro. Revista Brasileira de Sementes, v.16, n.2, p.116-120, 1994. http://www.bibl iotekevirtual.org/revistas/RBS/ v16n02/v16n02a03.pdf

TAVARES, L. C.; FONSECA, D. A. R.; BRUNES, A. P.; RUFINO, C. A.; MENEGUELLO, G. E.; BARROS, A. C. S. A. Performance of rice seeds treated with zinc, boron and molybdenum. Journal of Seed Science, v.35, p. 532-539, 2013a. http://www.scielo.br/pdf/jss/v35n4/16.pdf 
TAVARES, L. C.; RUFINO, C. A.; BRUNES, A. P.; FRIEDRICH, F. F.; BARROS, A. C. S. A.; VILLELA, F. A. Physiological performance of wheat seeds coated with micronutrients. Journal of Seed Science, v.35, n.1, p. 2834, 2013b. http://www.scielo.br/pdf/jss/v35n1/04.pdf

TAVARES, L. C.; BRUNES, A. P.; TUNES, L. M.; GADOTTI, G. I.; BARROS, A. C. S. A.; VILLELA, F. A. The yield and physiological quality of oat seeds subjected to cover with zinc. Acta Scientiarum, v.35, n.3, p.357361, 2013c. http://www.scielo.br/pdf/asagr/v35n3/v35n3a12.pdf

TAVARES, T. M.; SIEBENEICHLER, S. C.; LEAL, T. C. A. B.; TERRA, T. G. R.; ROTILI, E.; RAHMEIER, W. Growth analysis in seedlings rice in relation of the seed treatment with mineral nutrients. Journal of Biotechnology and Biodiversity, v.4, p.344-351, 2013. http://revista.uft.edu.br/index.php/ $\mathrm{JBB} /$ article/viewFile/623/359

TELES, T. G. R. M.; CARNEIRO, M. S. S.; SOARES, I.; PEREIRA, E. S.; SOUZA, P. Z.; MAGALHÃES, J. A. Produção e composição química da Brachiaria brizantha cv. MG-4 sob efeito de adubação com NPK. Acta Scientiarum, v.33, p.137-143, 2011. http://periodicos.uem.br/ojs/index.php/ ActaSciAnimSci/article/view/9392

VENDRAME, P. R. S.; BRITO, O. R.; GUIMARÃES, M. F.; MARTINS, E. S.; BECQUER, T. Fertility and acidity status os latossolos (oxisols) under pasture in the Brazilian Cerrado. Anais da Academia Brasileira de Ciências, v.82, p.1085-1094, 2010. http://www.scielo.br/pdf/aabc/v82n4/26.pdf
VICTOR, C. M. T.; FONSECA, D. M.; CÓSER, A. C.; MARTINS, C. E.; NASCIMENTO JÚNIOR, D.; RIBEIRO JÚNIOR, J. I. Produção de matéria seca e valor nutritivo de pastagem de capim-elefante sob irrigação e adubação nitrogenada. Revista Brasileira de Zootecnia, v.38, p.435-442, 2009. http:// www.scielo.br/pdf/rbz/v38n3/a06v38n3.pdf

XAVIER, P. B.; VIEIRA, H. D.; GUIMARÃES, C. P. Physiological potencial of stylosanthes cv. Campo Grande seeds coated with different materials. Journal of Seed Science, v.37, n.2, p.117-124, 2015. http://submission.scielo. br/index.php/jss/article/view/145982/9192

YAGI, R.; SIMILI, F. F.; ARAÚJO, J. C.; PRADO, R. M.; SANCHEZ, S. V.; RIBEIRO, C. E. R.; BARRETTO, V. C. M. Aplicação de zinco via sementes e seu efeito na germinação, nutrição e desenvolvimento inicial do sorgo. Pesquisa Agropecuária Brasileira, v.41, p.655-660, 2006. http://www.scielo. $\mathrm{br} / \mathrm{pdf} / \mathrm{pab} / \mathrm{v} 41 \mathrm{n} 4 / 29813 . \mathrm{pdf}$

YAMAGISHI, M.; YAMAMOTO, Y. Effects of boron on nodule development and symbiotic nitrogen fixation in soybean plants. Soil Science and Plant Nutrition, v.40, p.165-174, 1994. .http://www.tandfonline.com/doi/pdf/10.10 80/00380768.1994.10413300

WAZILEWSKI, W. T.; GOMES, L. F. S. Boro aplicado via semente em girassol. Cultivando o saber, v.2, n.2, p.137-142, 2009. 